\title{
PERAN KEMAMPUAN BERPIKIR LATERAL DAN POSITIF TERHADAP PRESTASI BELAJAR EVALUASI PENDIDIKAN
}

\author{
Leonard \\ FTMIPA Universitas Indraprasta PGRI \\ email: leoanova@yahoo.com
}

\begin{abstract}
Abstrak: Penelitian ini bertujuan untuk menganalisis peran kemampuan berpikir terhadap prestasi belajar mata kuliah evaluasi pendidikan. Penelitian ini adalah penelitian survei korelasional, dengan populasi mahasiswa pendidikan matematika UNINDRA. Sampel diambil dengan teknik multistage random sampling sejumlah 60 orang. Instrumen yang digunakan adalah angket dan tes. Analisis data menggunakan regresi berganda. Dari pengolahan data diperoleh hasil: (1) terdapat pengaruh kemampuan berpikir lateral terhadap prestasi belajar evaluasi pendidikan; (2) terdapat pengaruh kemampuan berpikir positif terhadap prestasi belajar evaluasi pendidikan; dan (3) terdapat pengaruh kemampuan berpikir lateral dan kemampuan berpikir positif secara bersama-sama terhadap prestasi belajar evaluasi pendidikan.
\end{abstract}

Kata Kunci: berpikir lateral, berpikir positif, prestasi belajar, evaluasi pendidikan

\section{THE ROLE OF LATERAL AND POSITIVE THINKING ON LEARNING ACHIEVEMENT OF EDUCATIONAL COURSES}

\begin{abstract}
This research aimed at analyzing the role of the thinking ability on learning achievement. The study applied a correlational survey research design. The population was the UNINDRA Mathematics education students. The sample, taken by a multistage random sampling technique, involved 60 students. The instruments were in the forms of questionnaires and tests. The data were analyzed using multiple regression. The findings showed that (1) lateral thinking ability had a positive and significant impact on learning achievement; (2) positive thinking ability had a positive and significant impact on learning achievement; (3) lateral thinking and positive thinking abilities had positive and significant simultaneous impact on learning achievement.
\end{abstract}

Keywords: lateral thinking, positive thinking, learning achievement

\section{PENDAHULUAN}

Pendidikan adalah upaya manusia untuk memanusiakan manusia, mengingat sasaran pendidikan adalah manusia. Pada dasarnya pendidikan bertujuan mengembangkan kemampuan dan potensi manusia sehingga dapat hidup layak, baik sebagai pribadi maupun sebagai anggota masyarakat dan diharapkan mampu menghasilkan SDM berkemauan dan berkemampuan untuk senantiasa meningkatkan kualitasnya secara terus menerus dan berkesinambungan (continuous quality improvement) (Mulyasa, 2009:7). Pendidikan bermaksud membantu peserta didik untuk menumbuhkembangkan potensi kemanusiaannya. Potensi kemanusiaan merupakan benih kemungkinan untuk menjadi manusia. Pendidikan juga merupakan kebutuhan utama manusia untuk meningkatkan taraf kehidupannya. 
Manusia adalah makhluk ciptaan Tuhan yang paling sempurna karena manusia telah dibekali dengan akal pikiran dan kecerdasan tinggi yang berasal dari otaknya yang membedakan manusia dengan makhluk lainnya. Otak sebagai tempat berlangsungnya proses berpikir merupakan aset berharga yang dimiliki oleh manusia. Bahkan, ketika manusia meninggal, otaknya masih dapat digunakan sebagai bahan penelitian dengan catatan kondisinya masih dalam keadaan baik. Dari otak, manusia dapat melakukan apapun melalui proses berpikir. Berpikir adalah hak asasi yang dimiliki oleh setiap orang. Siapapun tidak dapat melarang orang untuk berpikir apa dan dimana saja, sekalipun itu adalah seorang yang berkuasa.

Akan tetapi, tidak semua orang menyadari akan pentingnya aset berharga yang telah dibekali oleh Tuhan sehingga tidak sedikit orang yang melakukan sesuatu tanpa berpikir terlebih dahulu yang dampaknya adalah kerugian bagi dirinya sendiri maupun bagi orang lain. Seperti yang dikatakan oleh Will Dauranti (Madhi, 2009:38) bahwa masalah yang ada pada sebagian besar manusia adalah mereka berpikir dengan harapan, ketakutan, atau keinginan-keinginan mereka, bukan dengan akal sehat mereka.

Setiap orang memiliki cara berpikir masing-masing sehingga dari cara mereka berpikir akan mempengaruhi keputusan mereka dan akan berbeda-beda pula hasilnya. Tetapi, perbedaan dalam hal ini adalah sebuah keunikan dan bisa menjadi kesempurnaan ketika dikombinasi antara pemikiran yang satu dengan pemikiran yang lain. Cara berpikir juga dipengaruhi oleh kemampuan berpikir yang baik. Tidak heran orang-orang hebat dan sukses di dunia ini memiliki kemampuan berpikir yang hebat pula. Mereka yang berpikir seadanya, atau tidak mengasah kemampuan berpikirnya, maka kehidupannya pun akan biasa-biasa saja. Disadari atau tidak, sebagian besar orang hebat tersebut memiliki kemampuan berpikir yang tidak biasa, yang biasa dikenal dengan kemampuan berpikir lateral. Kemampuan berpikir ini tidak begitu saja datang, sekalipun ada bakat, kalau tidak dilatih maka kemampuan ini tidak dapat berguna dengan baik.

Sejak zaman Aristoteles, pola berpikir logis telah dikenal sebagai salah satu cara paling efektif didalam penggunaan kemampuan berpikir manusia, akan tetapi gambaran tentang lahirnya ide-ide baru nampaknya tidak selalu dihasilkan melalui proses berpikir secara logis. Beberapa orang diantara kita telah menyadari adanya suatu jenis pola berpikir yang lain, yang khususnya dengan amat mudah kita kenali ketika pola itu membawa kita kepada berbagai ide-ide sederhana, yang baru nampak jelas setelah kita pikirkan kembali bagaimana kita sampai pada hasil tersebut. Berpikir menurut Asmin (2005:529) adalah eksplorasi pengalaman yang dilakukan secara sadar dalam mencapai sesuatu tujuan. Tujuan itu mungkin berbentuk pemahaman, pengambilan keputusan, perencanaan, pemecahan masalah, penilaian, tindakan dan sebagainya.

Ditinjau dari proses pemecahan masalah yang dihadapi, maka fungsi gaya berpikir dapat dibagi dalam tujuh bagian utama, yaitu: berpikir vertikal, berpikir lateral, berpikir kritis, berpikir analitis, berpikir strategis, berpikir tentang hasil dan berpikir kreatif (Asmin, 2005: 532). Dari segi letaknya menurut Deporter dan Hernacki (Asmin, 2005: 532), semua gaya berpikir tersebut dikelompokkan seperti dalam Tabel 1.

\section{Tabel 1. Gaya Pemikiran Berdasarkan Belahan Otak}

\begin{tabular}{ll}
\hline Proses Otak Kiri & \multicolumn{1}{c}{$\begin{array}{c}\text { Proses Pemikiran Otak } \\
\text { Kanan }\end{array}$} \\
\hline Vertikal & Lateral \\
Kritis & Hasil \\
Strategis & Kreatif \\
Analitis & \\
\hline
\end{tabular}

Sumber: Asmin (2005:532) 
Pada dasarnya setiap tindakan yang dilakukan oleh manusia merupakan buah dari berpikir, tetapi tidak semua orang mau menggunakan otaknya untuk berpikir hal-hal yang baik, bagi apa yang akan dilakukannya, apalagi harus mempelajari dan merubah pola berpikirnya, agar memiliki kemampuan berpikir yang tidak biasa, yaitu berpikir lateral. Prinsip "air mengalir" membuat semua orang menjadi santai, tanpa kendali, seperti benar-benar mengalir mengikuti arus yang berjalan. Padahal, dengan menguasai berpikir lateral, akan mempermudah orang untuk memecahkan dan menyelesaikan masalah yang dihadapi.

Kemampuan berpikir lateral akan mengasah sisi kreatif dalam diri seseorang untuk mengatasi apapun yang dihadapi. Sudah jelas bahwa kemampuan ini bukan mempersulit tetapi justru mempermudah, tetapi yang menjadi masalah adalah kemauan untuk memulainya. Asmin (2005:533) mengatakan, otak belahan kiri berfungsi untuk berpikir rasional, analitis, berurutan linier, saintifik (seperti belajar, membaca, bahasa, aspek berhitung dari matematika), sedangkan otak belahan kanan berfungsi untuk berpikir holistik (berpikir berhubungan dengan sistem sebagai suatu keseluruhan), spasial (berkenaan dengn ruang dan tempat), metaphorik dan lebih banyak menyerap konsep matematika, sintesis, mengetahui sesuatu secara intuitif, olaborasi dan variabel serta dimensi humanistik mistik.

Istilah lateral thinking atau berpikir lateral dikemukakan pertama kali oleh Edward de Bono, seorang psikolog asal Malta. Berpikir lateral, adalah kemampuan untuk berpikir kreatif, atau "di luar kotak" dengan menggunakan inspirasi dan imajinasi untuk memecahkan masalah dengan melihat mereka dari perspektif yang tak terduga. De Bono (2009: 45) mengatakan, "the word "lateral" in relation to thinking means moving across patterns instead of moving along them- that is the nature and the logic of creativity”. Berpikir lateral meninggal- kan pemikiran cara tradisional, dan membuang prasangka. Berpikir lateral adalah memecahkan masalah melalui pendekatan langsung dan pendekatan kreatif, dengan menggunakan penalaran yang tidak segera jelas dan melibatkan ideide yang mungkin tidak diperoleh dengan hanya menggunakan tradisional langkah-demi-langkah logika. Asmin (2005: 538) mengemukakan bahwa berpikir lateral merubah cara dari tradisionil, dan bekerja untuk persepsi-persepsi baru pada objek yang sama. Selama berpikir vertikal meletakkan tekanan pada satu dimensi tunggal, maka berpikir lateral mencoba menangani masalah pembelajaran dari beberapa arah dan sudut pandang beragam sehingga melahirkan potensi yang lebih baik dalam kreativitas.

Secara alamiah, manusia merupakan makhluk yang sangat berharga, akan tetapi kondisi mental masing-masing individu, justru membuat individu tersebut tidak merasa berharga. Sukmadinata (2007:148) mengatakan perasaan diri berharga merupakan hal yang sangat penting dalam kesehatan mental, sebab mendasari kondisi dari komponen-komponen kesehatan mental lainnya. Perasaan diri berharga akan memperkuat keberadaan dirinya, dan sebaliknya, rasa diri tak berharga akan menggoyahkan keberadaan dirinya dalam kehidupannya. Seorang yang memiliki perasaan diri tak berharga, tidak akan memiliki ketenangan hidup, tidak akan memiliki harapan, banyak diliputi perasaan cemas, ragu, hampa dan bentuk-bentuk ketaktentuan lainnya. Berdasarkan pernyataan Sukmadinata tersebut, maka dapat dikatakan bahwa dengan merasa diri berharga, seseorang akan mampu memandang kehidupan secara positif.

Dengan arti lain, tindakan, pikiran, dan perkataannya selalu dilandasi oleh pikiran positif dan jauh dari kekhawatiran serta selalu optimis dalam segala aspek kehidupan. Kemampuan berpikir positif ini juga merupakan unsur yang penting dalam perkembangan psikologis 
seseorang, dengan berpikir positif seseorang dapat sukses menghadapi masa depan. Hal ini senada dengan apa yang diucapkan oleh Descrates (Amrin, 2009: 49) yang mengatakan, $a k u$ berpikir maka aku ada.

Tentama (2010: 68) mengatakan bahwa berpikir positif membuat individu mampu memusatkan perhatian pada hal-hal positif dari berbagai permasalahan yang dihadapi, atau dalam arti lain. Dengan berpikir positif, seseorang dapat menghadapi setiap permasalahan dengan semangat dan energi yang besar karena mampu melihat hal positif di balik kondisi yang kurang menyenangkan. Hal ini didukung pendapat Hill \& Ritt (Dwitantyanov, Hidayati, \& Sawitri, 2010:137) yang mengatakan berpikir positif juga membantu seseorang dalam memberikan sugesti positif pada diri saat menghadapi kegagalan, saat berperilaku tertentu, dan membangkitkan motivasi.

Kriteria individu yang cenderung berpikir positif adalah pertama, percaya pada kuasa Tuhan Yang Maha Esa. Kedua, selalu menjauh dari perilaku negatif seperti berbohong, menggunjing, mengadu domba, dan sebagainya. Ketiga, memiliki cara pandang, tujuan, dan alasan menginginkan sesuatu, kapan, serta bagaimana cara mendapatkannya dengan mengerahkan seluruh potensi serta kemungkinan yang ada. Keempat, memiliki keyakinan dan proyeksi tentang sesuatu secara positif. Kelima, selalu mencari jalan keluar dari berbagai masalah yang dihadapi. Keenam, belajar dari masalah dan kesulitan. Ketujuh, tidak membiarkan masalah atau kesulitan mepengaruhi hidupnya. Kedelapan, memiliki rasa percaya diri, menyukai perubahan, dan berani menghadapi tantangan. Kesembilan, hidup dengan cita-cita, perjuangan, dan kesabaran. Terakhir, pandai bergaul dan suka membantu orang lain (Dwitantyanov, Hidayati, \& Sawitri, 2010:138).

\section{METODE}

Penelitian ini menggunakan penelitian survei terhadap 60 orang mahasiswa, Peneliti mengambil data menggunakan instrumen yang telah divalidasi tanpa melakukan perlakuan terhadap subyek penelitian. Data yang terkumpul dianalisis untuk menyelesaikan permasalahan yang dirumuskan dalam bentuk rumusan masalah. Konstelasi masalah penelitian digambarkan dalam gambar hubungan antar variabel sebagai berikut.

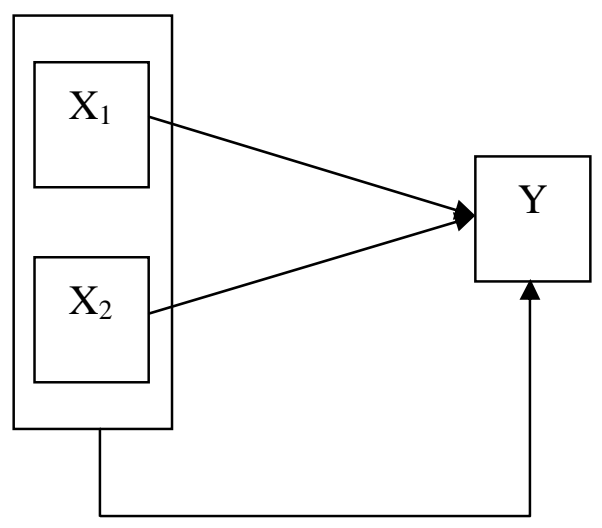

\section{Gambar 1. Desain Penelitian}

Keterangan:

$\mathrm{X}_{1} \quad=$ Kemampuan Berpikir Lateral

$\mathrm{X}_{2} \quad=$ Kemampuan Berpikir Positif

$\mathrm{Y}=$ Prestasi belajar Matematika

Sampel yang digunakan dalam penelitian ini sebanyak 60 orang mahasiswa, yang diambil dengan teknik multistage sampling, yaitu dengan purposive sampling untuk memilih rombongan belajar dan dengan random sampling untuk memilih responden. Instrumen yang digunakan adalah angket dengan skala likert untuk mengukur kemampuan berpikir lateral dan kemampuan berpikir positif. Data prestasi belajar dikumpulkan dengan tes yang dibuat oleh dosen. Instrumen terlebih dahulu divalidasi secara empiris. Uji coba instrumen dilakukan di kelas lain yang tidak dijadikan sampel. Data dianalisis terlebih dahulu dengan uji persyaratan, yaitu uji normalitas, uji linieritas dan uji multikolinieritas. Berdasarkan keterpenuhan 
kriteria dalam uji persyaratan analisis data, dilakukan analisis inferensial untuk pengujian hipotesis penelitian. Analisis inferensial menggunakan teknik analisis korelasi dan regresi berganda.

\section{HASIL DAN PEMBAHASAN \\ Hasil}

Secara deskriptif, data penelitian ini dapat dinyatakan dalam Tabel 2.

Tabel 2. Keterkaitan antara Berpikir Lateral, Berpikir Positif, dan Prestasi Belajar

\begin{tabular}{llll}
\hline $\begin{array}{l}\text { Statistik } \\
\text { Deskriptif }\end{array}$ & $\begin{array}{l}\text { Berpikir } \\
\text { Lateral }\end{array}$ & $\begin{array}{l}\text { Berpikir } \\
\text { Positif }\end{array}$ & $\begin{array}{l}\text { Prestasi } \\
\text { belajar }\end{array}$ \\
\hline Maksimum & 115 & 146 & 98 \\
Minimum & 55 & 68 & 38 \\
Rata-rata & 81,77 & 107,88 & 71,2 \\
Median & 84,0 & 108,0 & 72,0 \\
Modus & 85,0 & 97,0 & 78,0 \\
Simpangan & 12,91 & 19,96 & 14,71 \\
Baku & & & \\
\hline
\end{tabular}

Sumber: Data primer yang diolah

Dari tabel 2, terlihat bahwa kemampuan berpikir lateral tergolong cukup tinggi, hal ini terlihat dari nilai mean, median dan modus yang nilainya mendekati skor maksimum yang mungkin dicapai untuk variabel berpikir lateral, yaitu 100. Kemampuan berpikir positif tergolong sedang, terlihat dari nilai mean, median dan modus yang nilainya masih agak jauh dari skor maksimum yang mungkin dicapai untuk variabel berpikir positif, yaitu 160. Terakhir, prestasi belajar dapat dikatakan cukup tinggi, hal ini terlihat dari nilai mean, median dan modus yang nilainya mendekati skor maksimum yang mungkin dicapai untuk variabel prestasi belajar, yaitu 100 .

Sebelum dilakukan pengujian hipotesis, terlebih dahulu harus dilakukan pengujian asumsi, yaitu uji persyaratan analisis data, yang meliputi uji normalitas, uji linieritas, dan uji multikolinieritas. Hal ini dilakukan untuk menjamin bahwa data yang dianalisis tidak me- nyimpang dari kebenaran yang seharusnya (Tentama, 2010: 72).

Pengujian normalitas dilakukan untuk mengetahui distribusi data untuk setiap variabel yang diteliti normal atau tidak. Pengujian dilakukan menggunakan software SPSS 15.0 dengan kriteria pengujian adalah jika $p>0,05$ maka distribusi data dinyatakan normal, dan sebaliknya jika $p<0,05$ maka distribusi data dinyatakan tidak normal. Dari tabel 3 , terlihat bahwa seluruh variabel yang diteliti memiliki $p$ $>0,05$; sehingga dapat disimpulkan bahwa seluruh variabel dalam penelitian ini berdistribusi normal.

Tabel 3. Ringkasan Hasil Uji Normalitas

\begin{tabular}{llll}
\hline Variabel & $\begin{array}{l}\text { Skor } \\
\text { KS-Z }\end{array}$ & $p$ & Keterangan \\
& & \\
\hline Berpikir Lateral & 0,661 & 0,775 & Normal \\
Berpikir Positif & 0,397 & 0,997 & Normal \\
Prestasi belajar & 0,862 & 0,448 & Normal \\
\hline
\end{tabular}

Sumber: Data primer yang diolah

Pengujian linieritas menggunakan tabel bantuan ANOVA, yang dilihat dari hasil uji deviation from linearity. Pengujian ini dimaksudkan untuk melihat garis regresi yang terbentuk antara variabel bebas dengan variabel terikat, berpola garis lurus (linier) atau tidak, sehingga dapat dilakukan peramalan (forecasting). Pengujian dilakukan menggunakan software SPSS 15.0 dengan kriteria pengujian adalah jika $p>0,05$ maka persamaan garis berbentuk linier, dan sebaliknya jika $p<0,05$ maka persamaan garis berbentuk non linier. Dari tabel 4 , terlihat bahwa nilai $p$ deviation from liniearity untuk setiap variabel bebas terhadap variabel terikat $>0,05$; sehingga dapat disimpulkan memenuhi kelinieran regresi. Atau dalam arti lain, persamaan regresi yang terbentuk dapat digunakan untuk meramalkan kondisi yang akan terjadi pada variabel terikat, untuk setiap perubahan pada variabel bebas. 
Tabel 4. Ringkasan Hasil Uji Linieritas

\begin{tabular}{llll}
\hline $\begin{array}{l}\text { Garis yang } \\
\text { Diuji }\end{array}$ & Skor $\mathrm{F}$ & $p$ & Keterangan \\
\hline $\mathrm{X}_{1}$ atas $\mathrm{Y}$ & 1,334 & 0,223 & Linier \\
$\mathrm{X}_{2}$ atas $\mathrm{Y}$ & 0,757 & 0,760 & Linier \\
\hline
\end{tabular}

Sumber: Data primer yang diolah

Uji multikolinieritas menggunakan koefisien VIF (variance inflation factor), dimaksudkan untuk menguji hubungan antar variabel bebas, yaitu ada atau tidaknya hubungan yang kuat antara variabel kemampuan berpikir lateral dengan kemampuan berpikir positif. Kusnendi (2008:148) mengatakan bahwa untuk dapat dianalisis, harus dipenuhi beberapa asumsi, yaitu: (1) hubungan antarvariabel linier; dan (2) antarvariabel penyebab tidak terdapat problem multikolinieritas. Pengujian dilakukan menggunakan software SPSS 15.0 dengan kriteria pengujian adalah jika VIF > 10 atau Tolerance menjauhi angka 1 , maka terdapat masalah multikolinieritas, dan sebaliknya jika VIF $<10$ atau Tolerance mendekati angka 1 maka tidak terdapat masalah multikolinieritas. Dari tabel 5 terlihat bahwa nilai VIF < 10 dan nilai tolerance mendekati angka 1 , sehingga dapat disimpulkan tidak terjadi masalah multikolinieritas. Atau dengan kata lain, tidak terdapat hubungan kuat antara variabel bebas.

Tabel 5. Hasil Uji Multikolinieritas

\begin{tabular}{lccl}
\hline \multicolumn{1}{c}{ Variabel } & Tolerance & VIF & \multicolumn{1}{c}{ Keterangan } \\
\hline Berpikir & & & Tidak terjadi \\
Lateral \& & 0,872 & 1,147 & $\begin{array}{l}\text { malah } \\
\text { multikolinieritas }\end{array}$ \\
Berpikir & & & \\
Positif & & & \\
\hline
\end{tabular}

Sumber: Data primer yang diolah

Setelah semua asumsi persyaratan analisis data terpenuhi, selanjutnya dilakukan perhitungan pengujian hipotesis, yaitu dengan teknik korelasi dan regresi ganda, yang proses pengujiannya dilakukan menggunakan program SPSS 15.0. Dari pengolahan data diperoleh besar koefisien korelasi sebesar 0,813 ; nilai ini mengindikasikan ada korelasi yang sangat kuat antara kemampuan berpikir lateral dan berpikir positif secara bersama-sama terhadap prestasi belajar. Besar koefisien determinasi $66,1 \%$ yang berarti $66,1 \%$ variasi prestasi belajar dipengaruhi oleh kemampuan berpikir lateral dan berpikir positif, sedangkan sisanya dipengaruhi oleh faktor lain yang tidak dibahas dalam penelitian ini.

Secara individu, signifikansi setiap variabel bebas terhadap variabel terikat ditunjukkan melalui nilai $t_{\text {hitung }}$ atau signifikasinya. Hasil perhitungan menunjukkan bahwa untuk setiap variabel bebas diperoleh $p<0,05$; sehingga dapat disimpulkan secara individu setiap variabel bebas memberikan pengaruh positif dan signifikan terhadap variabel terikat.

Persamaan regresi yang terbentuk adalah $\mathrm{Y}=-12,565+0,479 \mathrm{X}_{1}+0,414 \mathrm{X}_{2}$. Hal ini diartikan bahwa jika kemampuan berpikir diabaikan, maka prestasi belajar -12,565; setiap penambahan 1 point pada kemampuan berpikir lateral akan menambah prestasi belajar sebesar 0,479; dan setiap penambahan 1 point pada kemampuan berpikir positif akan menambah prestasi belajar sebesar 0,414. Hasil uji signifikansi koefisien regresi diperoleh nilai $\mathrm{F}_{\text {hitung }}=$ 55,463 dengan $p=0,000$; sehingga dapat disimpulkan bahwa koefisien regresi yang terbentuk signifikan, atau dengan kata lain secara bersama-sama kemampuan berpikir memberi pengaruh positif dan signifikan terhadap prestasi belajar.

\section{Pembahasan}

Penelitian ini telah menemukan dan berhasil mengkorfimasi bahwa kemampuan berpikir lateral dan berpikir positif memberikan dampak positif yang berarti bagi perkembangan peserta didik, khususnya dalam pembelajaran evaluasi pendidikan. Pembelajaran yang baik merupakan pembelajaran yang memberikan kesempatan bagi peserta didik, untuk berkembang dan meningkatkan kompetensinya. Peningkatan kompetensi peserta didik, tentunya hanya bisa didapatkan melalui kegiatan pembelajaran yang kondusif dan menyenangkan 
bagi peserta didik. Prihastuti (2009:37) mengatakan bahwa pembelajaran menyenangkan berarti anak berada dalam keadaan yang sangat rileks, tidak ada sama sekali ketegangan yang mengancam dirinya, baik fisik maupun nonfisik. Kondisi menyenangkan secara umum akan memberikan kenyamanan bagi peserta didik, dalam hal ini mahasiswa sehingga memberikan kesempatan untuk mendayagunakan potensi yang dimilikinya.

Akan tetapi, kondisi ideal seperti ini tidak selalu terjadi dalam pembelajaran, justru proses pembelajaran menimbulkan kecemasan bagi peserta didik, seperti pembelajaran yang penuh dengan ketegangan dan sikap otoriter para pengajar. Kecemasan ternyata memberikan efek negatif terhadap prestasi belajar. Untuk itulah kemampuan berpikir menjadi penting, sehingga mahasiswa mampu mensiasati dan menemukan sikap, langkah atau tindakan terbaik untuk tetap mendapatkan materi yang baik walaupun kondisi pembelajaran tidak atau kurang menyenangkan. Sikap yang diambil mahasiswa untuk menghadapi masalah tergantung dari seberapa positif mereka berpikir tentang masalah tersebut, sedangkan langkah atau tindakan yang diambil mahasiswa sebagai cara memecahkan masalah akan tergantung dari seberapa baik kreatifitas dan kemampuan berpikir lateralnya. Dari data penelitian, terlihat bahwa sebagian besar responden memiliki kemampuan berpikir yang cukup baik, yang faktanya secara empiris berdampak positif pada prestasi belajarnya.

Membangun sikap atau cara pikir positif dapat dilakukan dengan cara-cara yang sederhana, seperti memberikan jargon kata-kata positif, memberikan motivasi dan lain sebagainya. Hal ini sama seperti yang dilakukan oleh Surya (2006), dengan konsep Mestakung (Semesta Mendukung) berusaha meyakinkan bahwa Indonesia bisa menjadi juara dunia dalam Olimpiade Fisika Internasional, dan akhirnya dapat dicapai. Proses ini tentu saja dilakukan untuk mempengaruhi pikiran bawah sadar, baik peserta maupun pelatih sehingga terdorong untuk bekerja keras mendukung tujuan menjadi juara dunia dalam Olimpiade Fisika Internasional ke-37 di Singapura. Kondisi ini juga didukung oleh Dwitantyanov, Hidayati, \& Sawitri (2010) yang menemukan bahwa pelatihan berpikir positif mampu meningkatkan efikasi diri, atau lebih dikenal dengan keyakinan manusia akan kemampuan dirinya.

Berpikir positif bukan hanya berakibat pada kesehatan mental, tetapi juga berakibat pada kesehatan fisik seseorang. Senada dengan pendapat Marcus Aurelius yang dikutip oleh Seto (2010), yang mengatakan, "kehidupan kita adalah apa yang pikiran-pikiran kita ciptakan". Dari data yang telah dikumpulkan terlihat bahwa sebagian besar siswa telah memiliki kemampuan berpikir positif yang baik, hal ini tentunya berdampak baik terhadap kondisi kejiwaan dan kesehatan siswa tersebut. Dengan berpikir positif kondisi kejiwaan kita menjadi lebih baik karena dapat menghalau datangnya pemikiran-pemikiran negatif yang dapat mengikis kesehatan seseorang. Suatu hambatan muncul ketika prasangka buruk dibiarkan mencekik ide-ide dan peluang-peluang dalam hidup. Biasanya hambatan dimulai dengan yang pertama hadir dalam pikiran. Dan prasangka kita adalah yang menghalangi kita dalam menelaah perspektif unik yang masing-masing orang berikan pada dunia luar. Berawal dari pemikiran yang positif dan selalu optimis akan mampu membuat kehidupan bathin dan lahiriah menjadi lebih baik.

Berpikir sehat dalam memandang sesuatu dari segala arah dapat menghasilkan suatu keputusan dan pemikiran yang terbaik tanpa harus mengikutsertakan emosi. Dengan berpikir positif seseorang akan berusaha lebih memahami dunia orang-orang di sekelilingnya. Dengan rasa ingin tahu tentang sudut pandang yang berbeda. Baik cara berpikir, bertindak, merasa, atau berintuisi, dapat melatih rasa ingin tahu. Dan hal ini dapat membantu seseorang melihat 
berbagai kemungkinan dari dunia yang terbuka dan bukan keterbatasan dari dunia yang tertutup. Dengan rasa ingin tahu itulah yang dapat mendorong seseorang untuk dapat mengatasi hambatan-hambatan yang membatasi kemampuan, sehingga dapat menemukan langkah yang lebih besar dan lebih baik. Hal ini senada dengan pendapat Abraham (2008: 46) yang mengatakan berpikir sebagai tindakan pikiran seseorang menghasilkan pemikiran.

Membangun langkah dan tindakan terbaik untuk memecahkan masalah, seperti telah diungkapkan sebelumnya, tergantung dari kemampuan berpikir lateral. Menurut Asmin (2005:539), berpikir lateral mempunyai peranan dalam melepaskan diri dari belenggu konsepsi yang lama, dan menghasilkan perubahan sikap serta pendekatan, untuk mengamati masalah dengan cara berbeda, yang semula senantiasa diamati dengan cara yang sama. Ketika seseorang memiliki kemampuan berpikir lateral, maka orang tersebut memiliki kemampuan dalam mencari ide dan persepsi yang baru, mengingat pola masalah tidak selalu simetris, maka diperlukan cara untuk memotong berbagai pola ini (bergerak lateral).

Kemampuan berpikir lateral menyediakan cara dimana kita dapat memotong berbagai pola, sekalipun tidak simetris. Maksudnya dalam kemampuan berpikir lateral dapat timbul sesuatu yang tidak mungkin menjadi mungkin untuk dipakai dalam menyelesaikan masalah. Kemampuan berpikir lateral akan mendorong penggunanya menjadi kreatif dalam berpikir. Kemampuan berpikir lateral tidak hanya terbatas dalam dunia bisnis saja, belakangan ini dapat diaplikasikan dalam berbagai bidang. Contohnya saja dalam dunia pendidikan. Dengan memiliki kemampuan berpikir lateral, peserta didik mampu mencari berbagai alternatif dalam mencari penyelesaian masalah yang dihadapi dalam pembelajaran. Kemampuan seperti ini diharapkan akan memberi pengaruh besar bagi peserta didik, sehingga tidak mudah mengalami kebuntuan dan cepat menyerah. De Bono (Asmin, 2005: 539) menegaskan bahwa pembebasan dari gagasan lama dan rangsangan terhadap yang baru merupakan aspek kembar dari berpikir lateral.

Dari penelitian ini juga ditemukan bahwa ternyata kemampuan berpikir setiap individu berbeda, dan tidak dapat dilakukan pemaksanaan kemampuan berpikir, sehingga perlu ada perlakuan berbeda terhadap masing-masing individu. Senada dengan pendapat Hasratudin (2008: 47) yang mengatakan, "kualitas berpikir manusia dapat dibagi atas tiga bagian, yaitu berpikir tingkat rendah, seperti mengingat, mengetahui dan memahami; berpikir tingkat sedang, seperti menerapkan, menggunakan dan mempraktekkan; berpikir tingkat tinggi, seperti analisis, sintesis, evaluasi, problem solving, berpikir kritis dan berpikir kreatif."

Penelitian ini telah menemukan dan membuktikan bahwa kemampuan berpikir memberikan manfaat dan pengaruh yang besar terhadap pencapaian prestasi belajar mahasiswa, khususnya pada mata kuliah evaluasi pendidikan. Di masa mendatang, diharapkan ada penelitian-penelitian yang bertujuan untuk mengetahui dan mengembangkan peran kemampuan berpikir, sehingga prestasi belajar yang optimal dapat tercapai.

\section{PENUTUP}

\section{Kesimpulan}

Pertama, terdapat pengaruh kemampuan berpikir lateral terhadap prestasi belajar evaluasi, yang diartikan semakin baik kemampuan berpikir lateral mahasiswa, maka semakin baik prestasi belajar evaluasinya. Kedua, terdapat pengaruh kemampuan berpikir positif terhadap prestasi belajar evaluasi, yang diartikan semakin baik kemampuan berpikir positif mahasiswa, maka semakin baik prestasi belajar evaluasinya. Ketiga, terdapat pengaruh kemampuan berpikir lateral dan kemampuan berpikir positif secara bersama-sama terhadap prestasi belajar 
evaluasi, yang diartikan semakin baik kemampuan berpikir lateral dan kemampuan berpikir positif mahasiswa secara bersama-sama, maka semakin baik prestasi belajar evaluasinya.

\section{Saran}

Dari hasil penelitian ini, maka penulis berusaha beberapa saran sebagai berikut.

- Pemerintah, melalui Kementrian Pendidikan dan Kebudayaan membuat kebijakan mengenai pentingnya pelaksanaan kurikulum berbasis kemampuan berpikir, dan juga mengaktifkan penulisan-penulisan bahan ajar berbasis kemampuan berpikir.

- Kampus, tentunya bekerjasama dengan dinas pendidikan atau instansi terkait mencoba mengadakan pelatihan-pelatihan kepada para dosen mengenai pengembangan kemampuan berpikir, sehingga dosen dapat mengimplementasikan kemampuan tersebut kepada mahasiswa.

- Mahasiswa, sebagai kaum intelektual mencoba melatih diri untuk berpikir, sehingga dapat menemukan pemecahan terbaik di tengah kondisi terburuk sekalipun, dan dapat memberikan pengaruh yang baik terhadap pembangunan di Indonesia secara umum.

- Perlu diadakan penelitian lanjutan, mungkin dilaksanakan dalam bentuk eksperimen, sehingga temuan-temuan dalam penelitian ini dapat diverifikasi dan disempurnakan.

\section{UCAPAN TERIMA KASIH}

Ucapan terima kasih penulis sampaikan kepada pimpinan Universitas Indraprasta PGRI, terutama Dekan FTMIPA, Dr. Supardi U.S., M.M., M.Pd., yang telah memberikan dukungan kepada penulis. Juga kepada rekan-rekan dari Lembaga Penelitian dan Pengabdian Masyarakat (LP2M) Universitas Indraprasta PGRI, yang menjadi tempat penulis bernaung selama ini. Terakhir, penulis juga mengucapkan terima kasih kepada Redaksi Jurnal Cakrawala Pendidikan yang memberi kesempatan kepada penulis untuk mempublikasikan hasil penelitian ini. Kiranya Tuhan yang membalas setiap kebaikan yang telah diberikan kepada penulis.

\section{DAFTAR PUSTAKA}

Abraham, A. 2008. Developing Your Personality by Positive Thinking, Terjemahan: Jasmine Amelia Putri. Yogyakarta: Quills Books Publisher.

Amrin, A. M. 2009. Cara Belajar Cerdas dan Efektif, Bukan Keras dan Melelahkan. Yogyakarta: Gerailmu.

Asmin. 2005. "Implementasi berpikir lateral dalam proses pembelajaran di sekolah". Jurnal Pendidikan dan Kebudayaan, 11 (55), 525-553.

De Bono, E. 2009. Think! Before It's Too Late. London: Vermilion.

Dwitantyanov, A., Hidayati, F., dan Sawitri, D.S. 2010. "Pengaruh Pelatihan Berpikir Positif pada Efikasi Diri Akademik Mahasiswa (Studi Eksperimen pada Mahasiswa Fakultas Psikologi UNDIP Semarang)". Jurnal Psikologi Undip, 8 (2), 135-144.

Hasratudin. 2008. "Meningkatkan Keterampilan Berpikir Kritis dan Kecerdasan Emosional melalui Pembelajaran Matematika Realistik". Prosiding Seminar Nasional Matematika Universitas Katolik Parahyangan 3, 45-56.

Madhi, J. 2009. Kreatif Berpikir. Surakarta: Ziyad Visi Media.

Kusnendi. 2008. Model-model Persamaan Struktural. Bandung: Alfabeta.

Mulyasa, E. 2009. Menjadi Guru ProfesionalMenciptakan Pembelajaran Kreatif dan 
Menyenangkan. Bandung: Remaja Rosdakarya.

Prihastuti. 2009. "Pengaruh Braingym terhadap Peningkatan Kecakapan Berhitung Siswa Sekolah Dasar". Cakrawala Pendidikan, 28(1), 35-47.

Seto, M. 2010. Wisdom Of Positif Thinking. Yogyakarta: New Diglossia.
Sukmadinata, N. S. 2007. Landasan Psikologi Proses Pendidikan. Bandung: Remaja Rosdakarya.

Surya, Y. 2006. MESTAKUNG Rahasia Sukses Juara Dunia Olimpiade Fisika. Jakarta: Hikmah.

Tentama, F. 2010. "Berpikir Positif dan Penerimaan Diri pada Remaja Penyandang Cacat Tubuh Akibat Kecelakaan”. Humanitas, 7 (1), 66-75. 